\title{
GMR
}

\section{Biological correlation between glucose transporters, Ki-67 and 2-deoxy-2-[18F]-fluoro-D-glucose uptake in diffuse large B-cell lymphoma and natural killer/T-cell lymphoma}

\author{
Y.M. Liu ${ }^{1,2}$, X.M. Zhai ${ }^{3}$ and Y.W. Wu ${ }^{4}$ \\ ${ }^{1}$ Department of Nuclear Medicine, Suzhou Kowloon Hospital, \\ Shanghai Jiaotong University School of Medicine, Suzhou, China \\ ${ }^{2}$ Department of Nuclear Medicine, School of Radiation Medicine and Protection, \\ Medical College of Soochow University, Suzhou, China \\ ${ }^{3}$ Department of Radiotherapy, The First Affiliated Hospital of Soochow University, \\ Suzhou, China \\ ${ }^{4}$ Department of Nuclear Medicine, \\ The First Affiliated Hospital of Soochow University, Suzhou, China \\ Corresponding author: Y.W. Wu \\ E-mail: yiweiwumed@yeah.net \\ Genet. Mol. Res. 15 (2): gmr.15027242 \\ Received July 17, 2015 \\ Accepted December 7, 2015 \\ Published May 6, 2016 \\ DOI http://dx.doi.org/10.4238/gmr.15027242
}

\begin{abstract}
The purpose of this study was to investigate the association between cellular 2-deoxy-2-[18F]-fluoro-D-glucose $\left({ }^{18} \mathrm{~F}-\mathrm{FDG}\right)$ uptake and the expression of several subtypes of glucose transporters (GLUT) and Ki-67 in diffuse large B-cell lymphoma (DLBCL) and natural killer (NK)/T-cell lymphoma (NKTCL). Cell lines were histologically determined to be DLBCL (Raji cells) and NKTCL (Daudi cells), and uptake after pretreatment with ${ }^{18} \mathrm{~F}-\mathrm{FDG}$ was determined. Real-time polymerase chain reaction was performed to detect the expression levels of GLUTs 1, 2, 3, 4, and 7 and Ki-67, and to evaluate their association with ${ }^{18} \mathrm{~F}-\mathrm{FDG}$ uptake in DLBCL and NKTCL cells. The uptake rates of ${ }^{18} \mathrm{~F}-\mathrm{FDG}$ ranged from 18 to $46 \%$ (average 30 $\pm 10.20 \%$ ) in Raji cells and 25 to $48 \%$ (average $35.6 \pm 7.57 \%$ ) in Daudi cells. In DLBCL cells, the expression levels of GLUTs 1, 3, and 7 were
\end{abstract}


significantly correlated with cellular ${ }^{18} \mathrm{~F}-\mathrm{FDG}$ uptake rates (Spearman's rank correlation coefficient of $0.667,0.516$, and 0.468 , respectively; $\mathrm{P}$ $<0.05)$. In NKTCL cells, the expression levels of GLUTs 1 and 3 were observed to be significantly correlated with cellular ${ }^{18} \mathrm{~F}-\mathrm{FDG}$ uptake rates (Spearman's rho of 0.756 and 0.498, respectively; $\mathrm{P}<0.05$ ). Ki-67 played no role in ${ }^{18} \mathrm{~F}-\mathrm{FDG}$ uptake in Raji or Daudi cells. In conclusion, the data acquired through this preliminary study indicate that GLUT 1 and GLUT 3 contribute to ${ }^{18}$ F-FDG uptake in DLBCL and NKTCL.

Key words: Diffuse large B-cell lymphoma; Natural killer T-cell lymphoma; Glucose transporters; 2-Deoxy-2-[18F]-fluoro-D-glucose; Ki-67;

Real-time polymerase chain reaction

\section{INTRODUCTION}

Non-Hodgkin's lymphoma (NHL) is the sixth leading type of cancer in men and fifth in women. It consists of a heterogeneous group of lymphoproliferative disorders originating in B-cell, T-cell, or natural killer (NK) lymphocytes (Zelenetz et al., 2010). The different types of NHL show variability in biology, histology, immunology, clinical manifestation, and outcome. According to the National Comprehensive Cancer Network (NCCN), each pathology type of NHL should be treated as an independent disease (Kho et al., 2008). Diffuse large B-cell lymphoma (DLBCL) is the most common subtype of NHL and is clinically heterogeneous. Forty percent of DLBCL patients respond well to current therapy and have prolonged survival, whereas the remainder succumb to the disease (Alizadeh et al., 2000). Treatment strategies to improve outcomes have largely included increased doses of standard agents in the context of autologous stem cell transplantation (Glass et al., 2010). Therefore, there is a great medical need to define the genetic abnormalities that are associated with DLBCL to define novel targets for therapy (Lohr et al., 2012).

Another subtype of NHL is NK/T-cell lymphoma (NKTCL) and refers to a group of clonal proliferations of cytotoxic lymphocytes of NK or, more rarely, T-cells. The clinicopathologic features of NKTCL are peculiar, arising mainly as tumors (Schmitt et al., 2011). It is an aggressive disease with a poor prognosis and, in the absence of effective treatment, the median survival for advanced-stage disease is only 6-12 months (Jaccard et al., 2011). Moreover, NKTCL remains difficult to cure, and the need for alternative therapeutic strategies has prompted researchers to explore oncogenic genes involved in order to provide new molecular targets (Kwong et al., 2014).

Patients with DLBCL and NKTCL were examined in this study. Patients suffering from malignant neoplasms will often undergo serial positron emission tomography/computed tomography (PET/CT) scans, using 2-deoxy-2-[18F]-fluoro-D-glucose $\left({ }^{18} \mathrm{~F}-\mathrm{FDG}\right)$, for initial diagnosis. This is followed by preoperative staging, restaging, and prediction of prognosis, including follow-up during treatment to detect relapse (Hirose et al., 2014). PET/CT with ${ }^{18} \mathrm{~F}-\mathrm{FDG}$ has become a standard procedure within oncology during recent years. To the best of our knowledge, few studies have been reported regarding the relationship between intracellular ${ }^{18} \mathrm{~F}-\mathrm{FDG}$ uptake and immunohistochemical markers affecting ${ }^{18} \mathrm{~F}-\mathrm{FDG}$ such as glucose transporters (GLUTs) and Ki-67 in DLBCL and NKTCL (Malik et al., 2014). Hence, 
the purpose of this study was to investigate the association between intracellular ${ }^{18} \mathrm{~F}$-FDG uptake and the expression level of GLUTs and Ki-67 in DLBCL and NKTCL.

\section{MATERIAL AND METHODS}

\section{Cell culture}

The Raji cell line, originating from human DLBCL, was obtained from the Jiangsu Institute of Hematology, and the Daudi cell line, originating from human NKTCL, was obtained from the Department of Immunology of Soochow University. The two cell lines were cultured in Roswell Park Memorial Institute-1640 media (RPMI-1640; Gibco, Grand Island, NE, USA) supplemented with $10 \%$ fetal bovine serum (Gibco) and penicillin-streptomycin $(100 \mathrm{U} / \mathrm{mL})$ at $37^{\circ} \mathrm{C}$ with $100 \%$ humidity and $5 \% \mathrm{CO}_{2}$.

\section{${ }^{18}$ F-FDG uptake}

DLBCL and NKTCL cells were seeded at $1 \times 10^{6} /$ well on 6-well plates (Corning, New York, USA) for $24 \mathrm{~h}$, and then the culture medium was exchanged with glucose-free culture medium. After 8 h, $50 \mu \mathrm{L}{ }^{18} \mathrm{~F}-\mathrm{FDG}$ (CNMTH, Nanjing, China), dissolved in $0.9 \%$ $\mathrm{NaCl}$ solution to a final concentration of $0.74 \mathrm{kBq} / \mu \mathrm{L}$, was added to each well and the cells were incubated for $100 \mathrm{~min}$ at $37^{\circ} \mathrm{C}$ and $5 \% \mathrm{CO}_{2}$. The treated cells were centrifuged for $5 \mathrm{~min}$ at $100 \mathrm{~g}$ (Eppendorf 5415, Sartorius, Germany) to remove the original medium completely. The precipitate was washed twice with $1 \mathrm{~mL}$ ice-cold phosphate-buffered solution (PBS) per well and then put into tubes A (DLBCL) and B (NKTCL). PBS solution $(1 \mathrm{~L})$ was made by dissolving $8.0 \mathrm{~g} \mathrm{NaCl}, 0.2 \mathrm{~g} \mathrm{KCl}, 0.24 \mathrm{~g} \mathrm{KH}_{2} \mathrm{PO}_{4}$ and $1.44 \mathrm{~g} \mathrm{Na}_{2} \mathrm{HPO}_{4} \times 12 \mathrm{H}_{2} \mathrm{O}$ in water and then diluted $\mathrm{HCl}$ was used to adjust the $\mathrm{pH}$ to 7.1-7.2 (TOLEDO 320, METTLER, Switzerland). The radioactivity of ${ }^{18} \mathrm{~F}-\mathrm{FDG}$ was calculated by a Packard 5600 gamma counter. In addition, a normal control was assessed in identically treated cells that were not incubated with ${ }^{18} \mathrm{~F}-\mathrm{FDG}$.

\section{RNA extraction}

A total of $1 \mathrm{~mL}$ PBS and $6 \mathrm{~mL}$ RNA later were added to tubes A and $\mathrm{B}$. The mixture was kept at $4{ }^{\circ} \mathrm{C}$ overnight and then stored at $-20^{\circ} \mathrm{C}$. Frozen DLBCL and NKTCL cells were ground using a mortar and pestle in liquid nitrogen. Total RNA was extracted using TRIzol reagent (Invitrogen, Carlsbad, CA, USA) according to the manufacturer protocol.

\section{Real-time polymerase chain reaction (PCR)}

For first-strand cDNA synthesis, $1.2 \mathrm{mg}$ RNA was mixed with $4.5 \mu \mathrm{L}$ master mix, which included 0.6 U/ $\mu \mathrm{L}$ RNase-free DNase I, $0.3 \mu \mathrm{L}$ RNA guard and $2 \mathrm{mM} \mathrm{MgCl}_{2}$, and brought up to $30 \mu \mathrm{L}$ with water. The reactions were performed in $200-\mu \mathrm{L}$ PCR tubes and incubated at $37^{\circ} \mathrm{C}$ for $10 \mathrm{~min}$ and then $90^{\circ} \mathrm{C}$ for $5 \mathrm{~min}$ in a thermal cycler (DK-80, Fine MacroLaboratory Equipment Co. Ltd., Shanghai, China). Next, the RNA/primer mix was used in $25-\mu \mathrm{L}$ reactions containing $1.25 \mu \mathrm{L}$ RNA guard, $20 \mathrm{mM}$ DTT, $2 \mathrm{X}$ SuperScript II buffer, 2 $\mathrm{mM}$ dNTPs and 6.25 U SuperScript II reverse transcriptase (all reagents from New England 
Biolabs, UK). The reactions were incubated for $45 \mathrm{~min}$ at $42^{\circ} \mathrm{C}, 10 \mathrm{~min}$ at $75^{\circ} \mathrm{C}$, and adjusted to a final volume of $50 \mu \mathrm{L}$. For second-strand cDNA synthesis, PCRs contained $0.125 \mu \mathrm{M}$ specific primers, $0.2 \mathrm{mM}$ dNTPs, $1 \mathrm{U}$ Taq DNA polymerase, 10X PCR Buffer and $2 \mu \mathrm{L}$ firststrand cDNA. Specific primers for GLUTs and Ki-67 (Sangon Bioengineering Co., Shanghai, China) are displayed in Table 1. Primer specificity was confirmed by conventional PCR using an Eppendorf Vapo-Protect Master cycler (Hamburg, Germany).

The cDNA was diluted (1:50) in $99 \mu \mathrm{L}$ water. To each sample, $20 \mu \mathrm{L}$ master mix and $5 \mu \mathrm{L}$ diluted cDNA were added. Real-time PCR was conducted with a Bio-Rad iCycler optical system using an iQTM SYBR Green PCR kit (Bio-Rad Laboratories, Hercules, CA, USA) with 40 cycles of $15 \mathrm{~s}$ at $95^{\circ} \mathrm{C}$ and $60 \mathrm{~s}$ at $60^{\circ} \mathrm{C}$.

Table 1. Real-time PCR primers for GLUTs, Ki-67, and GAPDH.
\begin{tabular}{l|l|c|r}
\hline & Primers sequences $\left(5{ }^{\prime} \rightarrow 3\right.$ ') & Ta $\left({ }^{\circ} \mathrm{C}\right)$ & Length (bp) \\
\hline GLUT1 & GCTACCCTGGATGTCCTATCTG & 56.6 & 211 \\
\hline GLUT2 & ACCACACAGTTGCTCCACATAC & 56.6 & 207 \\
\hline GLUT3 & AACTAACAGACACTGCCACGAG & 56.6 & 211 \\
\hline GLUT4 & GGGTTCCTCTTCTACTGGGTTT & 56.6 & 207 \\
\hline GLUT7 & GTGGAGAACTTGGAAATGGAA & 56.6 & 211 \\
\hline Ki-67 & ACCGTTGAAGAGAGTGGAGTG & 55.0 & 209 \\
\hline GAPDH & CAAGGTCATCCATGACAACTTTG & 59.0 & 496 \\
\hline
\end{tabular}

$\mathrm{Ta}=$ annealing temperature.

\section{Determination of gene of interest and internal control gene}

Both the gene of interest and internal control were amplified. Plot diagrams were drawn to detect the $\mathrm{Ct}$ (y-axis) versus $\log$ (cDNA dilution) (x-axis) and determine the slope of the line. PCR efficiency was then calculated by the equation $\mathrm{E}=10^{-1 / \mathrm{m}}$, where $\mathrm{E}$ was the PCR efficiency and $m$ was the slope of the line. We selected GAPDH as the internal control gene in this experiment. The Student $t$-test was performed to determine whether the expression of the internal control gene varied under the experimental conditions.

\section{Pfaffl method}

In addition to determining the expression profile of a target gene under experimental conditions, the relative abundance of the target gene in relation to other genes of interest may also be determined with the use of a reference gene (Masuda et al., 2013). In general, relative quantification is a simple and efficient method to assess an assay, but absolute quantification may be more informative due to the ability to interpret results across different assay platforms (Dussault and Pouliot, 2006). Relative quantification of GLUTs and Ki-67 was detected by the Pfaffl method implemented in the fluorescence quantitative PCR detection system (Line-Gene FQD-33A, Bioer, Hangzhou, China) (Gardner, 2010), and the ratio was calculated as follows:

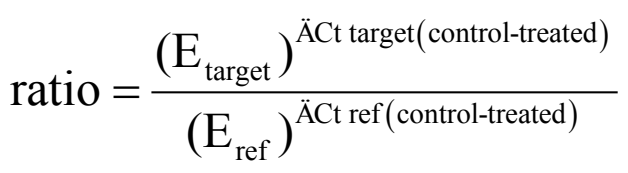


where $E_{\text {target }}$ is the amplification efficiency for the target gene and $E_{r e f}$ is the amplification efficiency for the internal control gene.

\section{Statistical analysis}

Each experiment was performed at least in triplicate and the results were processed using the Statistical Product and Service Solutions software (SPSS, Chicago, IL, USA) (Bryman and Cramer, 2005). The data are reported as means \pm standard deviation. Correlations between ${ }^{18} \mathrm{~F}-\mathrm{FDG}$ uptake and various immunohistochemical markers (GLUTs and Ki-67) were analyzed utilizing the Spearman rank test. $\mathrm{P}<0.05$ was considered to be statistically significant.

\section{RESULTS}

\section{Cellular ${ }^{18}$ F-FDG uptake rates}

The ${ }^{18} \mathrm{~F}-\mathrm{FDG}$ uptake rates in DLBCL cells ranged from 18 to $46 \%$ (average $30 \pm 10.20 \%$ ), while the uptake rates were 25 to $48 \%$ (average $35.6 \pm 7.57 \%$ ) for NKTCL cells $(\mathrm{N}=10)$. We found that the average ${ }^{18} \mathrm{~F}-\mathrm{FDG}$ uptake rate of DLBCL cells was lower than NKTCL cells.

\section{RNA extraction and reverse transcription}

After RNA extraction from DLBCL and NKTCL cells, the immunofluorescence of isolated RNA was captured and is shown in Figure 1A. Subsequently, RNA was reacted with SuperScript II reverse transcriptase to synthesize cDNA (Figure 1B).
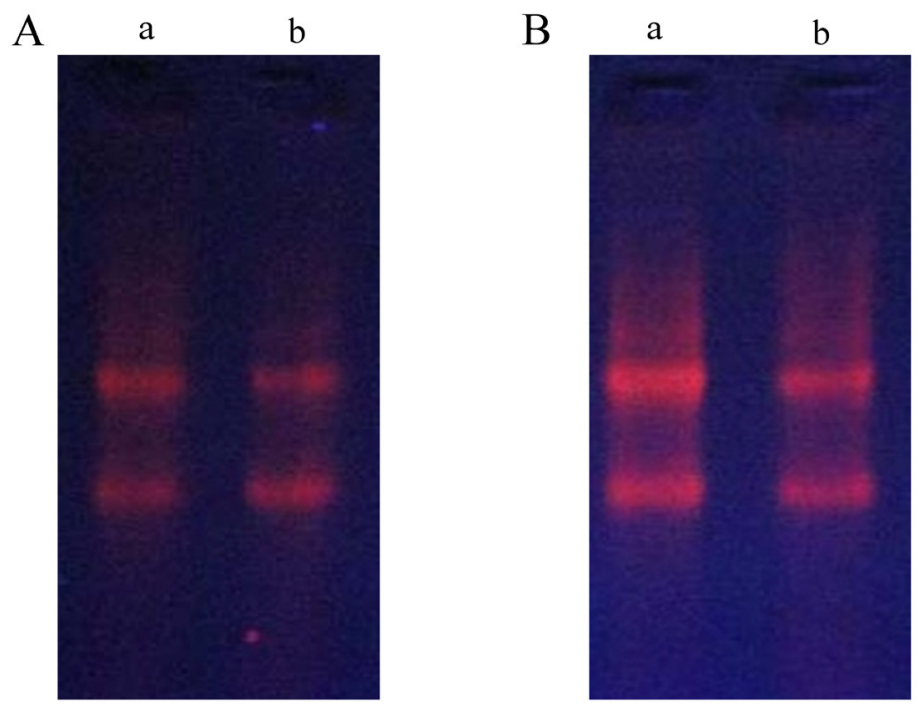

Figure 1. Immunofluorescence results of RNA extraction (A) and reverse transcription (B). RNA origin: lane $a$ :Raji cells from DLBCL and lane $b$ :Daudi cells from NKTCL. 


\section{Real-time PCR assays}

For each cDNA, three technical replicates were run in all real-time PCR experiments, and all samples for one marker product were run on the same 96-well plate to minimize interexperimental variation. Dilution curves of the candidate reference gene (GAPDH) showed an average amplification efficiency of $100.1 \%$ (minimum, $89 \%$ and maximum, $111.3 \%$ ) and an average coefficient of determination $\left(\mathrm{R}^{2}\right)$ of 0.998 . Single distinctive peaks in the curves confirmed specific amplification of the gene of interest. This reliable detection indicates integrity of the cDNA samples. Starting quantities were based on the gene-specific standard curves. The relative expression levels for GLUTs and Ki-67 in DLBCL and NKTCLare shown in Figure 2. Relative expression levels of GLUT 1, GLUT 3, GLUT 4, and Ki-67 in DLBCL cells were lower than in NKTCL cells. The top three highly expressed markers were the same in both DLBCL and NKTCL cells (GLUT 1, GLUT 3 and Ki-67).

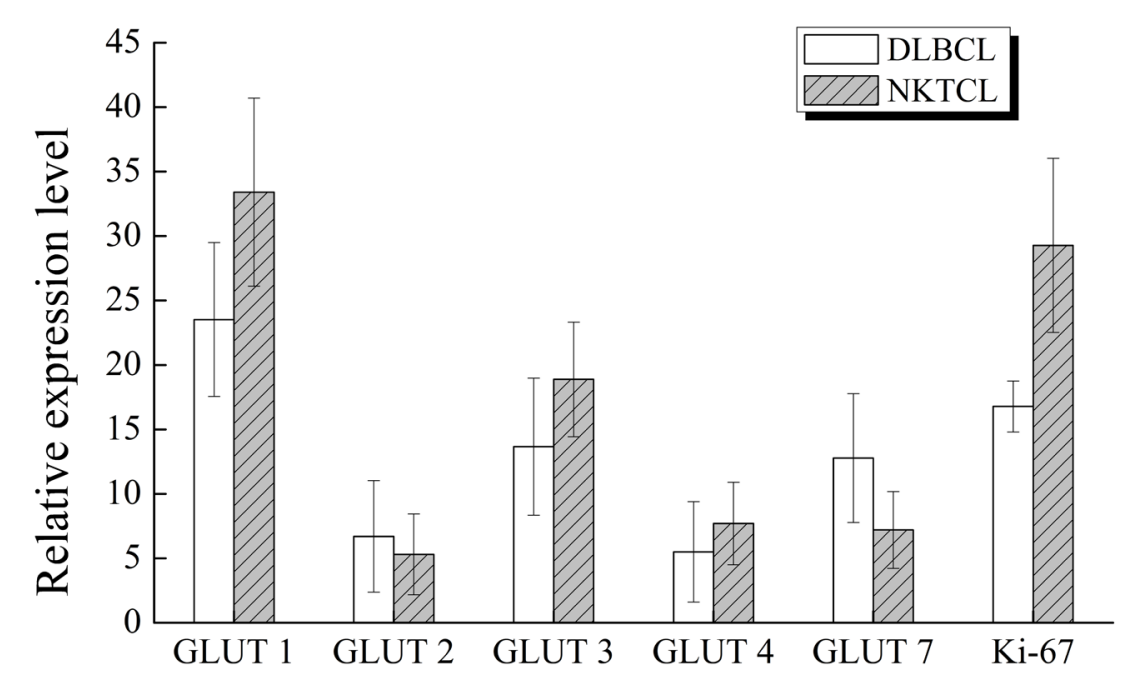

Figure 2. Relative expression levels of GLUTs and Ki-67 in DLBCL and NKTCL.

In Raji cells from DLBCL, GLUT 1 showed the most significant relative expression level (23.52 \pm 5.97$)$, and GLUT 3 and GLUT 7 were moderately expressed (13.66 \pm 5.32 and $12.78 \pm 5.0$, respectively). However, GLUT 2 and GLUT 4 showed lower relative expression levels ( $6.7 \pm 4.33$ and $5.5 \pm 3.9$, respectively). Ki-67 showed a moderate expression level (16.78 \pm 1.98 ). In Daudi cells from NKTCL, the most significantly expressed marker was GLUT 1 (33.41 \pm 7.29$)$, followed by Ki-67 (29.28 \pm 6.75$)$. GLUT 3 was moderately expressed at a level of $18.88 \pm 4.35$. The other GLUTs (GLUTs 1, 2, 4, and 7) showed lower relative expression.

\section{Relationship between ${ }^{18}$ F-FDG uptake and immunohistochemical markers}

The relationship between ${ }^{18} \mathrm{~F}-\mathrm{FDG}$ uptake and relative expression levels of immunohistochemical markers in DLBCL and NKTCL was evaluated using the Spearman 
rank test and the results are illustrated in Figure 3. If $\mathrm{P}<0.05$, we considered the correlation statistically significant. P $>0.05$ indicated no correlation between marker and ${ }^{18} \mathrm{~F}-\mathrm{FDG}$ uptake. In DLBCL cells, GLUT 1, GLUT 3 and GLUT 7 expression levels revealed a significant correlation with ${ }^{18} \mathrm{~F}$-FDG uptake rate. Only GLUT 1 and GLUT 3 correlated with ${ }^{18} \mathrm{~F}-\mathrm{FDG}$ uptake in NKTCL cells. Meanwhile, there was no distinct relationship in either Raji or Daudi cells for Ki-67.

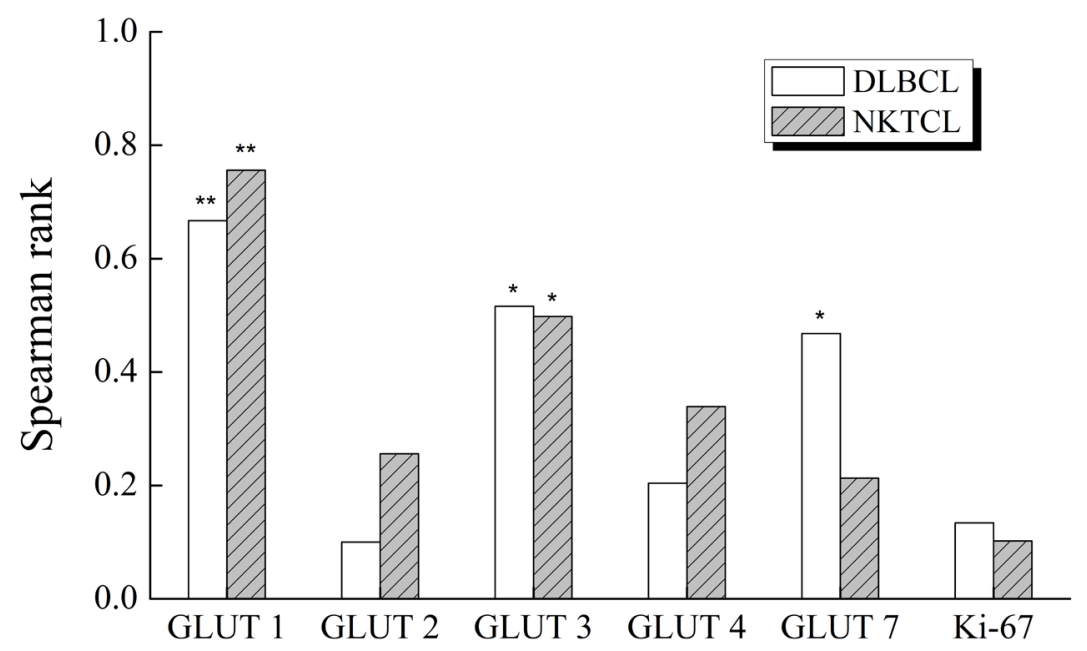

Figure 3. Correlation between gene expression and ${ }^{18} \mathrm{~F}-\mathrm{FDG}$ uptake in DLBCL and NKTCL cells. $* * \mathrm{P}<0.01$; $* 0.01<\mathrm{P}<0.05$.

\section{DISCUSSION}

To date, a number of published studies have revealed that GLUTs affect ${ }^{18} \mathrm{~F}-\mathrm{FDG}$ uptake in malignant tumors (Watanabe et al., 2012; Calcagni et al., 2013). However, these studies rarely examine multiple subtypes of GLUTs, and no definitive conclusion has been drawn in cellular ${ }^{18} \mathrm{~F}$-FDG uptake and the respective immunoreactivity of the different GLUTs. This is the first study to evaluate cellular ${ }^{18} \mathrm{~F}-\mathrm{FDG}$ uptake rates and quantify GLUTs by real-time PCR in two different pathology subtypes of NHL. Moreover, it could be helpful to understand the variation in efficiency and mechanism of ${ }^{18} \mathrm{~F}-\mathrm{FDG}$ accumulation in different pathology subtypes of NHL. In the present study, two different types of NHL cells, which originated from DLBCL Raji cells and NKTCL Daudi cells, were evaluated and then the association between cellular ${ }^{18} \mathrm{~F}-\mathrm{FDG}$ uptake and the relative expression levels of GLUT 1, GLUT 2, GLUT 3, GLUT 4, GLUT 7, and Ki-67 was examined. The results displayed a statistically significant correlative link between cellular ${ }^{18} \mathrm{~F}-\mathrm{FDG}$ uptake and GLUT 1, GLUT 3 and GLUT 7 in Raji cells and GLUT 1 and GLUT 3 in Daudi cells. Ki-67 played no role in ${ }^{18} \mathrm{~F}-\mathrm{FDG}$ uptake.

${ }^{18} \mathrm{~F}-\mathrm{FDG}$ is an analogue of glucose and uses a similar transport system as glucose (Bohnen et al., 2012). In tumor cells, especially malignant tumor cells from lung cancer (Liao et al., 2012), breast cancer (Groheux et al., 2011) and NHL (Alongi et al., 2014; Singh et al., 2014), ${ }^{18} \mathrm{~F}-\mathrm{FDG}$ accumulation rises dramatically. Zhang et al. (2013) demonstrated that 
different subtypes of lymphoma manifest in markedly different intensities of ${ }^{18} \mathrm{~F}-\mathrm{FDG}$ uptake, but most lesions of lymphoma had high uptake rates of ${ }^{18} \mathrm{~F}-\mathrm{FDG}$. In addition, metabolic activity was lower in indolent B-cell NHL than in aggressive B-cell NHL and T-cell lymphoma. When performed after 2 cycles of immunochemotherapy and interpreted according to the International Harmonization Project criteria, early response assessment with ${ }^{18} \mathrm{~F}-\mathrm{FDG}$ PET/ CT had a highly negative predictive value but low-positive predictive value in patients with advanced-stage DLBCL (Cashen et al., 2011).

GLUT 1 is the only GLUT subtype that exists in almost all tumor cell lines, where it has a high expression level resulting from microenvironment changes that occur during aggressive growth of malignant cells (Kim et al., 2013). It had been reported that the content of GLUT 1 increases with tumor malignancy and ${ }^{18} \mathrm{~F}-\mathrm{FDG}$ PET examination of the positive rate also increased upon detection of GLUT 1 content in bone and soft tissue (van Berkel et al., 2014). ${ }^{18}$ F-FDG circulation times and glucose levels significantly affect FDG uptake in the aortic and carotid walls and may bias the results of image interpretation in patients undergoing vascular ${ }^{18} \mathrm{~F}$-FDG PET/CT (Bucerius et al., 2014). GLUT 3 is a neuron-specific subtype of the GLUT family and has been demonstrated to play an important role in ${ }^{18} \mathrm{~F}$-FDG uptake in cancers of the nervous system, lymphoma and thyroid cancer (Tian et al., 2004; Shim et al., 2009; Hirose et al., 2014). Our results were consistent with the above studies, and we can infer that GLUT 1 and GLUT 3 have considerable impact on intracellular ${ }^{18} \mathrm{~F}$-FDG uptake in DLBCL and NKTCL. Furthermore, our results suggest that transport rates of GLUT 1 and GLUT 3 may be a rate-limiting step of intracellular ${ }^{18} \mathrm{~F}-\mathrm{FDG}$ uptake in Raji and Daudi cells.

$\mathrm{Ki}-67$ is strictly associated with cell proliferation and is an excellent marker to determine the growth fraction of a given cell population. Ki-67 is a valuable prognostic predictor of lymphoma, but its utility varies in lymphoma subtypes (He et al., 2014). It is also a strong predictor of central nervous system relapse in patients with mantle cell lymphoma (Chihara et al., 2015). Ki-67 is highly expressed in NKTCL patients and may be a valuable indicator for predicting the survival of NKTCL patients (Huang et al., 2014), which our results also confirmed. However, there was no statistically significant correlation between this biological marker and cellular ${ }^{18} \mathrm{~F}-\mathrm{FDG}$ uptake in this study. While it had no impact on cellular ${ }^{18} \mathrm{~F}-\mathrm{FDG}$ uptake, Ki-67 may affect intracellular ${ }^{18} \mathrm{~F}-\mathrm{FDG}$ accumulation by other mechanisms, which requires further investigation.

In conclusion, ${ }^{18} \mathrm{~F}-\mathrm{FDG}$ uptake of DLBCL and NKTCL was closely related to GLUT1, GLUT3 and GLUT7 expression levels, as evaluated by real-time PCR. There was no significant relationship between Ki-67 reactivity and cellular ${ }^{18} \mathrm{~F}-\mathrm{FDG}$ uptake.

\section{Conflicts of interest}

The authors declare no conflict of interest.

\section{REFERENCES}

Alizadeh AA, Eisen MB, Davis RE, Ma C, et al. (2000). Distinct types of diffuse large B-cell lymphoma identified by gene expression profiling. Nature 403: 503-511. http://dx.doi.org/10.1038/35000501

Alongi P, Fallanca F, Incerti E, Gianolli L, et al. (2014). Diagnostic accuracy of 18F-FDG PET/CT for end of treatment evaluation of HL and NHL: A comparison of Deauville Criteria (DC) with International Harmonization Project Criteria (IHPC). In: The 27th Annual EANM Congress, October 2014, Gothenburg, Sweden. Paper presented in 
European Journal of Nuclear Medicine and Molecular Imaging 41: S182.

Bohnen NI, Djang DS, Herholz K, Anzai Y, et al. (2012). Effectiveness and safety of 18F-FDG PET in the evaluation of dementia: a review of the recent literature. J. Nucl. Med. 53: 59-71. http://dx.doi.org/10.2967/jnumed.111.096578

Bryman A and Cramer D (2005). Quantitative Data Analysis with SPSS 12 and 13. Published by Routledge (New York).

Bucerius J, Mani V, Moncrieff C, Machac J, et al. (2014). Optimizing 18F-FDG PET/CT imaging of vessel wall inflammation: the impact of $18 \mathrm{~F}-\mathrm{FDG}$ circulation time, injected dose, uptake parameters, and fasting blood glucose levels. Eur. J. Nucl. Med. Mol. Imaging 41: 369-383. http://dx.doi.org/10.1007/s00259-013-2569-6

Calcagni ML, Mattoli MV, Blasi MA, Petrone G, et al. (2013). A prospective analysis of ${ }^{18} \mathrm{~F}$-FDG PET/CT in patients with uveal melanoma: comparison between metabolic rate of glucose (MRglu) and standardized uptake value (SUV) and correlations with histopathological features. Eur. J. Nucl. Med. Mol. Imaging 40: 1682-1691. http://dx.doi. org/10.1007/s00259-013-2488-6

Cashen AF, Dehdashti F, Luo J, Homb A, et al. (2011). 18F-FDG PET/CT for early response assessment in diffuse large B-cell lymphoma: poor predictive value of international harmonization project interpretation. J. Nucl. Med. 52: 386392. http://dx.doi.org/10.2967/jnumed.110.082586

Chihara D, Asano N, Ohmachi K, Nishikori M, et al. (2015). Ki-67 is a strong predictor of central nervous system relapse in patients with mantle cell lymphoma (MCL). Ann. Oncol. 26: 966-973. http://dx.doi.org/10.1093/annonc/mdv074

Dussault AA and Pouliot M (2006). Rapid and simple comparison of messenger RNA levels using real-time PCR. Biol. Proced. Online 8: 1-10. http://dx.doi.org/10.1251/bpo114

Gardner SW (2010). Investigation of intergenic regions of Mycoplasma hyopneumoniae and development of statistical methods for analyzing small-scale RT-qPCR assays. Doctoral Dissertation, Iowa State University, Paper 11238. http://lib.dr.iastate.edu/etd/11238.

Glass B, Ziepert M, Reiser M, Freund M, et al. (2010). High-dose therapy followed by autologous stem-cell transplantation with and without rituximab for primary treatment of high-risk diffuse large B-cell lymphoma. Ann. Oncol. 21: 22552261. http://dx.doi.org/10.1093/annonc/mdq235

Groheux D, Giacchetti S, Moretti JL, Porcher R, et al. (2011). Correlation of high 18F-FDG uptake to clinical, pathological and biological prognostic factors in breast cancer. Eur. J. Nucl. Med. Mol. Imaging 38: 426-435. http://dx.doi. org/10.1007/s00259-010-1640-9

He X, Chen Z, Fu T, Jin X, et al. (2014). Ki-67 is a valuable prognostic predictor of lymphoma but its utility varies in lymphoma subtypes: evidence from a systematic meta-analysis. BMC Cancer 14: 153. http://dx.doi.org/10.1186/1471$\underline{2407-14-153}$

Hirose Y, Suefuji H, Kaida H, Hayakawa M, et al. (2014). Relationship between 2-deoxy-2-[(18)F]-fluoro-d-glucose uptake and clinicopathological factors in patients with diffuse large B-cell lymphoma. Leuk. Lymphoma 55: 520-525. http://dx.doi.org/10.3109/10428194.2013.807509

Huang X, Sun Q, Fu H, Zhou X, et al. (2014). Both c-Myc and Ki-67 expression are predictive markers in patients with extranodal NK/T-cell lymphoma, nasal type: a retrospective study in China. Pathol. Res. Pract. 210: 351-356. http:// dx.doi.org/10.1016/j.prp.2014.02.004

Jaccard A, Gachard N, Marin B, Rogez S, et al. (2011). Efficacy of L-asparaginase with methotrexate and dexamethasone (AspaMetDex regimen) in patients with refractory or relapsing extranodal NK/T-cell lymphoma, a phase 2 study. Blood 117: 1834-1839. http://dx.doi.org/10.1182/blood-2010-09-307454

Kho ME, Lepisto EM, Niland JC, Friedberg JW, et al. (2008). Reliability of staging, prognosis, and comorbidity data collection in the National Comprehensive Cancer Network (NCCN) non-Hodgkin lymphoma (NHL) multicenter outcomes database. Cancer 113: 3209-3212. http://dx.doi.org/10.1002/cncr.23911

Kim JY, Shin SJ, Park KU, Jeon YJ, et al. (2013). Ciglitazone increases ovarian cancer cell death by inhibiting GLUT-1 expression. Cancer Res. 73: 1865-1865. http://dx.doi.org/10.1158/1538-7445.AM2013-1865

Kwong YL, Pang AW, Leung AY, Chim CS, et al. (2014). Quantification of circulating Epstein-Barr virus DNA in NK/Tcell lymphoma treated with the SMILE protocol: diagnostic and prognostic significance. Leukemia 28: 865-870. http://dx.doi.org/10.1038/leu.2013.212

Liao S, Penney BC, Wroblewski K, Zhang H, et al. (2012). Prognostic value of metabolic tumor burden on 18F-FDG PET in nonsurgical patients with non-small cell lung cancer. Eur. J. Nucl. Med. Mol. Imaging 39: 27-38. http://dx.doi. org/10.1007/s00259-011-1934-6

Lohr JG, Stojanov P, Lawrence MS, Auclair D, et al. (2012). Discovery and prioritization of somatic mutations in diffuse large B-cell lymphoma (DLBCL) by whole-exome sequencing. Proc. Natl. Acad. Sci. U. S. A. 109: 3879-3884. http:// dx.doi.org/10.1073/pnas.1121343109

Malik AI, Akhtar N, Loya A and Yusuf MA (2014). Endoscopic ultrasound - fine needle aspiration of 2-deoxy-2-[18F] fluoro-D-glucose avid lymph nodes seen on positron emission tomography- computed tomography -what looks like 
cancer may not always be so. Cancer Imaging 14: 27.

Masuda K, Kuwano Y, Nishida K and Rokutan K (2013). Application of DNA microarray technology to gerontological studies. Methods Mol. Biol.1048: 285-308. http://dx.doi.org/10.1007/978-1-62703-556-9_19

Schmitt C, Sako N, Bagot M, Huang Y, et al. (2011). Extranodal NK/T-cell lymphoma: toward the identification of clinical molecular targets. J. Biomed. Biotechnol. 2011: 790871. http://dx.doi.org/10.1155/2011/790871

Shim HK, Lee WW, Park SY, Kim H, et al. (2009). Relationship between FDG uptake and expressions of glucose transporter type 1, type 3, and hexokinase-II in Reed-Sternberg cells of Hodgkin lymphoma. Oncol. Res. 17: 331337. http://dx.doi.org/10.3727/096504009787721177

Singh H, Abrar M, Gorla A, Singh B, et al. (2014). Extranodal Site involvement (ENSI) in Non-Hodgkin's Lymphoma (NHL)-Role of 18F-FDG PET/CT. In: The 27th Annual EANM Congress, October 2014, Gothenburg, Sweden. Paper presented in European Journal of Nuclear Medicine and Molecular Imaging 41: S511-S512.

Tian M, Zhang H, Nakasone Y, Mogi K, et al. (2004). Expression of Glut-1 and Glut-3 in untreated oral squamous cell carcinoma compared with FDG accumulation in a PET study. Eur. J. Nucl. Med. Mol. Imaging 31: 5-12. http:// dx.doi.org/10.1007/s00259-003-1316-9

vanBerkel A, Rao JU, Kusters B, Demir T, et al. (2014). Correlation between in vivo 18F-FDG PET and immunohistochemical markers of glucose uptake and metabolism in pheochromocytoma and paraganglioma. J. Nucl. Med.55: 1253-1259. http://dx.doi.org/10.2967/jnumed.114.137034

Watanabe M, Abe N, Oshikiri Y, Stanbridge EJ, et al. (2012). Selective growth inhibition by glycogen synthase kinase-3 inhibitors in tumorigenic HeLa hybrid cells is mediated through NF-kB-dependent GLUT3 expression. Oncogenesis 1: e21. http://dx.doi.org/10.1038/oncsis.2012.21

Zelenetz AD, Abramson JS, Advani RH, Andreadis CB, et al. (2010). Non-Hodgkin's Lymphomas. J. Natl. Compr. Canc. Netw. 8: 288-334.

Zhang J, Wang RF, Fan Y, Fu Z, et al. (2013). Metabolic activity measured by 18F-FDG PET/CT in newly diagnosed patients with lymphoma: Correlation with immunophenotype. In: 2013 Society of Nuclear Medicine Annual Meeting, June 2013, Vancouver, BC. J. Nucl. Med. Meeting Abstr. 54: 1563. 